\title{
Mutation of the gene encoding a major outer- membrane protein in Xanthomonas campestris pv. campestris causes pleiotropic effects, including loss of pathogenicity
}

\author{
Yih-Yuan Chen, ${ }^{1}$ Chieh-Hao Wu, ${ }^{1}$ Juey-Wen Lin, ${ }^{2}$ Shu-Fen Weng ${ }^{1}$ \\ and Yi-Hsiung Tseng ${ }^{3}$ \\ ${ }^{1}$ Institute of Molecular Biology, National Chung Hsing University, Taichung 402, Taiwan, ROC \\ ${ }^{2}$ Institute of Biochemistry, National Chung Hsing University, Taichung 402, Taiwan, ROC \\ ${ }^{3}$ Institute of Microbiology, Immunology and Molecular Medicine, Tzu Chi University, Hualien 907, \\ Taiwan, ROC
}

Correspondence

Yi-Hsiung Tseng

yhtseng@mail.tcu.edu.tw

Shu-Fen Weng

sfweng@dragon.nchu.edu.tw

Received 3 March 2010

Revised 26 May 2010

Accepted 31 May 2010

\begin{abstract}
Xanthomonas campestris pv. campestris $(\mathrm{Xcc})$ is the phytopathogen that causes black rot in crucifers. The xanthan polysaccharide and extracellular enzymes produced by this organism are virulence factors, the expression of which is upregulated by Clp (CRP-like protein) and DSF (diffusible signal factor), which is synthesized by RpfF. It is also known that biofilm formation/ dispersal, regulated by the effect of controlled synthesis of DSF on cell-cell signalling, is required for virulence. Furthermore, a deficiency in DSF causes cell aggregation with concomitant production of a gum-like substance that can be dispersed by addition of DSF or digested by exogenous endo- $\beta$-1,4-mannanase expressed by Xcc. In this study, Western blotting of proteins from a mopB mutant (XcMopB) showed Xcc MopB to be the major outer-membrane protein (OMP); Xcc MopB shared over $97 \%$ identity with homologues from other members of Xanthomonas. Similarly to the rpfF mutant, XcMopB formed aggregates with simultaneous production of a gummy substance, but these aggregates could not be dispersed by DSF or endo$\beta$-1,4-mannanase, indicating that different mechanisms were involved in aggregation. In addition, XcMopB showed surface deformation, altered OMP composition, impaired xanthan production, increased sensitivity to stressful conditions including SDS, elevated temperature and changes in $\mathrm{pH}$, reduced adhesion and motility and defects in pathogenesis. The finding that the major OMP is required for pathogenicity is unprecedented in phytopathogenic bacteria.
\end{abstract}

\section{INTRODUCTION}

In Gram-negative bacteria, outer-membrane proteins (OMPs) play key roles in the structural integrity of the outer membrane $(\mathrm{OM})$ and function as transporters, membrane pores, recognition proteins, membrane-bound enzymes or components of signal transduction cascades (Bishop, 2008; Koebnik et al., 2000; Kostakioti et al., 2005). The OMPs of bacterial animal pathogens are required for normal growth and resistance to stressful conditions; such proteins include OprF of Pseudomonas aeruginosa (Gotoh et al., 1989; Rawling et al., 1998; Woodruff \& Hancock, 1989) and OmpA of Escherichia coli (Wang, 2002). OMPs may also play important roles in pathogenesis, for example, OspC of Borrelia burgdorferi (Pal et al., 2004), OmpA of E.

Abbreviations: Clp, CRP-like protein; DSF, diffusible signal factor; IM, inner membrane; OM, outer membrane; OMP, outer-membrane protein; $\mathrm{Xcc}$, Xanthomonas campestris pv. campestris. coli (Khan et al., 2003; Prasadarao et al., 1996; Wang, 2002), Opa and OpcA of Neisseria meningitidis (Moore et al., 2005), PagC of Salmonella typhimurium (Miller et al., 1992), Ail of Yersinia enterocolitica (Miller et al., 1989, 1990) and OmpA of Acinetobacter baumannii (Choi et al., 2008). OMPs of bacterial plant pathogens have also been shown to be involved in pathogenicity in several instances. For example, in Dickeya dadantii (Erwinia chrysanthemi), $\mathrm{HrcC}$, required for a functional type III secretion system, has been implicated in virulence (Yang et al., 2002), HecA, an adhesin, is important in virulence and contributes to attachment, aggregation and epidermal cell killing (Rojas et al., 2002) and TolC is involved in resistance to antimicrobial plant chemicals and in the survival and colonization of the pathogen in plant tissues (Barabote et al., 2003). In Xanthomonas, mutation in the Xanthomonas oryzae pv. oryzae $x a d A$ gene caused a deficiency in virulence (Ray et al., 2002), and HrpA1 of Xanthomonas campestris pv. 
vesicatoria has been shown to be essential for pathogenicity in host plants and induction of a hypersensitive reaction in non-host plants (Wengelnik et al., 1996). None of these OMPs of bacterial plant pathogens has been shown to be a major OMP.

Species of the Gram-negative genus Xanthomonas, mostly plant-pathogenic organisms, can be further divided into various pathovars depending on the plant hosts infected (Dye et al., 1980; Swings \& Civerolo, 1993). For example, $X$. campestris pv. campestris (Xcc) is the causative agent of black rot in crucifers (William, 1980). The OMPs of 54 isolates representing 16 pathovars of $X$. campestris have been resolved by SDS-PAGE. It was found that heterogeneity in OMP profiles existed within individual pathovars, and that a $37 \mathrm{kDa}$ protein was the most abundant in all nine isolates of pv. campestris (Ojanen et al., 1993). In addition, similarly to other Gram-negative bacteria, Xcc can liberate outer-membrane vesicles (OMVs) from the OM during growth, and it was found that the OMV proteome did not contain all highabundance OMPs (Sidhu et al., 2008). Despite these findings, none of the OMPs has been studied further, and the roles of these proteins in pathogenicity have not been investigated.

In the present study, we show that Xcc MopB is the major OMP and that mutation of the encoding gene results in pleiotropic effects, including changes in cell-surface architecture, formation of cell aggregates, reduced adhesion, motility and EPS productivity and loss of pathogenicity.

\section{METHODS}

Bacterial strains and culture conditions. The bacterial strains and plasmids used in this study are listed in Table 1. Unless otherwise indicated, Luria-Bertani (LB) broth or LB agar (Miller, 1972) was used to grow Xcc and E. coli at 28 and $37{ }^{\circ} \mathrm{C}$, respectively. XOLN (Fu \& Tseng, 1990) is a basal salt medium and was supplemented with $0.0625 \%(\mathrm{w} / \mathrm{v})$ yeast extract and $0.0625 \%(\mathrm{w} / \mathrm{v})$ tryptone. For measurements of Xcc growth, overnight cultures were diluted into $30 \mathrm{ml} \mathrm{LB}$ medium to obtain an initial $\mathrm{OD}_{550}$ of 0.35 , followed by growth at $28{ }^{\circ} \mathrm{C}$ unless otherwise specified; the $\mathrm{OD}_{550}$ was measured at appropriate intervals. When the effect of $\mathrm{pH}$ on growth was tested, the medium was adjusted to $\mathrm{pH}$ 5.0-9.0 using citrate buffer and the $\mathrm{OD}_{550}$ was measured $16 \mathrm{~h}$ later. To test for sensitivity to SDS, the detergent was added at concentrations of up to $0.02 \%(\mathrm{w} / \mathrm{v})$ and the $\mathrm{OD}_{550}$ was measured $8 \mathrm{~h}$ later. The following antibiotics were added when required $\left(\mu \mathrm{g} \mathrm{ml}^{-1}\right)$ : ampicillin (50), kanamycin (50), tetracycline (15), gentamicin (15).

Enzymes and chemicals. Restriction endonucleases were purchased from Takara Biochemicals. Taq DNA polymerase and PCR-related materials were obtained from either Merck or Takara Biochemicals. Laboratory-grade chemicals were purchased from Sigma or Merck. Synthetic diffusible signal factor (DSF; cis-11-methyl-2-dodecenoic acid) was obtained from Cayman Chemical (Ann Arbor, MI, USA).

DNA techniques, SDS-PAGE and Western blotting. DNA manipulations were performed as described in Sambrook \& Russell (2001). Transformation of Xcc cells was achieved by electroporation (Wang \& Tseng, 1992). Bacterial proteins were separated by SDSPAGE $(12 \%, w / v)$, followed by staining of protein bands with Coomassie brilliant blue R-250. For Western blotting, proteins were transferred electrophoretically to PVDF membranes (Hybond-P; Amersham Pharmacia Biotech). After blocking, nitrocellulose sheets were incubated with primary antibody (mouse anti-MopB antiserum,

Table 1. Bacterial strains and plasmids used in this study

$\mathrm{Ap}^{\mathrm{r}}$, Ampicillin resistance; $\mathrm{Gm}^{\mathrm{r}}$, gentamicin resistance; $\mathrm{Km}^{\mathrm{r}}$, kanamycin resistance; $\mathrm{Tc}^{\mathrm{r}}$, tetracycline resistance.

\begin{tabular}{|c|c|c|}
\hline Strain or plasmid & Relevant genotype or characteristics & Reference or source \\
\hline \multicolumn{3}{|l|}{$\begin{array}{l}X . \text { campestris pv. } \\
\text { campestris }\end{array}$} \\
\hline XсMopB & $m o p B$ mutant derived from $\mathrm{Xc17}, \mathrm{Ap}^{\mathrm{r}} \mathrm{Km}^{\mathrm{r}}$ & This study \\
\hline $\mathrm{XcRpfF}$ & $r p f F$ mutant derived from $\mathrm{Xc17}, \mathrm{Ap}^{\mathrm{r}} \mathrm{Gm}^{\mathrm{r}}$ & Hsiao et al. (2009) \\
\hline \multicolumn{3}{|l|}{ E. coli } \\
\hline BL21/DE3 & $\mathrm{F}^{-}$omp $T h s d S B\left(\mathrm{r}_{\mathrm{B}}^{-} \mathrm{m}_{\mathrm{B}}^{-}\right) g a l d c m$ met (DE3) & Novagen \\
\hline \multicolumn{3}{|l|}{ Plasmid } \\
\hline pOK12 & E. coli general cloning vector derived from $\mathrm{P} 15 \mathrm{~A}$ replicon, with $\operatorname{lac} \mathrm{Z} \alpha$ fragment, $\mathrm{Km}^{\mathrm{r}}$ & Vieira \& Messing (1991) \\
\hline pRK415 & Broad-host-range vector derived from RK2, with lac $\alpha \alpha$ fragment, $\mathrm{Tc}^{\mathrm{r}}$ & Keen et al. (1988) \\
\hline pET-30b & Expression vector, $\mathrm{Km}^{\mathrm{r}}$ & Novagen \\
\hline pRK-mopB & $\begin{array}{l}1183 \text { bp PCR fragment amplified from mopB (nt }-85 \text { to } 1098 \text { relative to translation } \\
\text { start site) and cloned into pRK415 }\end{array}$ & This study \\
\hline pET-mopB & pET-30b derivative with 1095 bp NdeI-XhoI fragment carrying the Xc17 mopB gene & This study \\
\hline pET-manA924 & pET-30b derivative with $924 \mathrm{bp} \mathrm{NdeI-XhoI} \mathrm{fragment} \mathrm{carrying} \mathrm{the} \mathrm{Xc17} \mathrm{manA} \mathrm{gene}$ & Hsiao et al. (2010) \\
\hline
\end{tabular}


diluted $1: 100000)$ and next with alkaline-phosphatase-conjugated anti-mouse IgG antibody (Promega) (diluted 1:5000), used as the secondary antibody. Reactive proteins were detected using BCIP/NBT substrate solution (PerkinElmer Life and Analytical Sciences).

Sequence analysis. Multiple alignment of protein sequences was carried out using CLUSTAL $\mathrm{W}$, a dendrogram was constructed using TreeView (Page, 1996) and signal peptides were predicted using the SignalP 3.0 program from ExPASy (http://www.cbs.dtu.dk/services/ SignalP/). Conserved OmpA domains were identified employing the CDD program from NCBI (http://www.ncbi.nlm.nih.gov/Structure/ cdd/cdd.shtml).

Construction of a mopB mutant and a complemented strain. A mopB mutant of $\mathrm{Xc17}$, XcMopB, was constructed by insertional mutation. A 500 bp DNA fragment internal to Xc17 mopB (nucleotide positions $301-800$ relative to the $\operatorname{mop} B$ initiation codon) was amplified by PCR with primers mopB-F (5'-GAAGGCCGCGGCTGGAACCC- $\left.3^{\prime}\right)$ and mopB-R (5'-GCATCCGGACGCAGGGTCGACT- $3^{\prime}$ ) using Xc17 chromosomal DNA as the template. The amplicon was ligated into the EcoRV site of the E. coli vector pOK12, which cannot be maintained in Xcc, resulting in plasmid pOK-mopB. After sequence verification, $\mathrm{pOK}-m o p B$ was introduced into $\mathrm{Xc17}$ by electroporation and transformants were selected on LB medium supplemented with kanamycin. Insertional inactivation of mopB by integration of pOKhybridization and Western blotting (not shown).

For genetic complementation, the complete mopB gene (a $1183 \mathrm{bp}$ DNA fragment; nt -85 to 1098 relative to the mopB initiation codon) was amplified by PCR using Xc17 chromosomal DNA as the template and cloned into the broad-host-range vector pRK415. The primers used were mopBC-F (5'-AAGCTTGCCCCGATGGCTCTGG-3') and mopBC-R (5'-TCTAGATTAGTTCTGGACGTTCAGCTCG-3'). The amplified fragment was ligated into EcoRV-digested pOK12. After verification of the sequence, the insert was excised using HindIII and $\mathrm{XbaI}$ and ligated into $\mathrm{pRK} 415$. The resulting plasmid $\mathrm{pRK}-m o p B$ was introduced into the mopB mutant XcMopB to form the complemented strain XcMopB(pRK-mopB).

Fractionation of Xcc cells. Fractionation of Xcc cells was carried out as described by Browning et al. (2003) and Tadayyon et al. (1994), with some modifications. Two $80 \mathrm{ml}$ cultures of each strain, with growth commencing at $\mathrm{OD}_{550} 0.35$, were grown overnight and then centrifuged at $6000 \mathrm{~g}$ at $4{ }^{\circ} \mathrm{C}$ for $5 \mathrm{~min}$. Cells were suspended in cold TM buffer ( $10 \mathrm{mM}$ Tris, pH 8.0 , containing $8 \mathrm{mM} \mathrm{MgSO}_{4}$ ), washed three times, resuspended in $4.0 \mathrm{ml}$ of the same buffer and passed four times through an Aminco French press at a pressure of 18000 p.s.i. Unbroken cells and cell debris were removed by centrifugation at $14000 \mathrm{~g}$ at $4{ }^{\circ} \mathrm{C}$ for $30 \mathrm{~min}$. Supernatants were then centrifuged at $135000 \mathrm{~g}$ at $4{ }^{\circ} \mathrm{C}$ for $1 \mathrm{~h}$. Supernatants, containing cytoplasmic and periplasmic proteins, were retained. Pellets, containing membranes and ribosomes, were suspended in $1.0 \mathrm{ml}$ cold TM buffer by gentle aspiration and ejection using a 25-gauge needle attached to a $1 \mathrm{ml}$ syringe, and resuspended samples were centrifuged at $135000 \mathrm{~g}$ as before. Pellets were rinsed with $1.0 \mathrm{ml}$ cold TM buffer, resuspended in $3.9 \mathrm{ml} 0.25 \%(\mathrm{w} / \mathrm{v})$ Sarkosyl and loaded into $3.9 \mathrm{ml}$ ultracentrifuge tubes. After incubation at room temperature for $1 \mathrm{~h}$, the tubes were centrifuged at $135000 \mathrm{~g}$ for $1 \mathrm{~h}$, as above. Supernatants, containing the Sarkosyl-soluble inner membrane (IM), were retained. The Sarkosyl-insoluble pellets, containing OM fractions, were washed twice with $1.0 \mathrm{ml} 0.25 \%(\mathrm{w} / \mathrm{v})$ Sarkosyl, incubated at room temperature for $1 \mathrm{~h}$ and centrifuged at $135000 \mathrm{~g}$ as described above. The pellets, containing the OM fraction, were suspended in $40 \mu \mathrm{l}$ cold TM buffer.

Protein concentrations in Sarkosyl-soluble and Sarkosyl-insoluble fractions were determined using a Bio-Rad detergent-compatible protein assay kit (catalogue no. 500-0012) and a regular Bio-Rad protein assay kit (catalogue no. 500-0006), respectively.

Expression and purification of recombinant MopB and preparation of antibodies against MopB. The $1095 \mathrm{bp}$ DNA fragment containing the complete $m o p B$ sequence (nt 1-1095 relative to the $m o p B$ initiation codon) was amplified by PCR using Xc17 chromosomal DNA as the template and primers mopBNdeI-F $\left(5^{\prime}\right.$ CATATGAACAAGAAAATTCTCACTGCCG-3') and mopBXhoI-R (5'-CTCGAGGTTCTGGACGTTCAGCTC- $\left.3^{\prime}\right)$, with the underlined nucleotides representing novel NdeI and XhoI recognition sites, respectively. The amplicon was cloned using an ECOS TA cloning kit (Yeastern). The cloned mopB-containing DNA fragment, after confirmation of identity by sequencing, was excised using $N d e I$ and $X h o \mathrm{I}$ and ligated into pET30b. The resulting plasmid $\mathrm{pET}-m o p B$ was introduced into E. coli strain BL21(DE3) for expression of recombinant MopB, which had six His residues attached to the $\mathrm{C}$ terminus.

Cells of E. coli BL21(DE3)(pET-mopB) were grown at $28{ }^{\circ} \mathrm{C}$ with shaking (150 r.p.m.) to an $\mathrm{OD}_{600}$ of 1.0 , isopropyl $\beta$-D-thiogalactopyranoside (IPTG) was added to a final concentration of $0.25 \mathrm{mM}$ and growth was continued for $4 \mathrm{~h}$ at $28{ }^{\circ} \mathrm{C}$. Cells were harvested by centrifugation at $10000 \mathrm{~g}$ for $15 \mathrm{~min}$, resuspended in buffer A (20 mM Tris/HCl, pH 8.0, containing $0.5 \mathrm{M} \mathrm{NaCl}, 5 \mathrm{mM}$ imidazole, $6 \mathrm{M}$ urea and $1 \mathrm{mM}$ PMSF) and sonicated on ice. Unbroken cells and cell debris were removed by centrifugation at $12000 \mathrm{~g}$ for $30 \mathrm{~min}$. The supernatant was filtered through a $0.45 \mu \mathrm{m}$ membrane filter and applied to a column (Bio-Rad Econo-Pac) containing $\mathrm{Ni}^{2+}$-chelating column Sepharose Fast Flow resin (Amersham Bioscience) for affinity binding. The column was washed with buffer B $(20 \mathrm{mM}$ Tris/ $\mathrm{HCl}$, $\mathrm{pH} 8.0$, containing $0.5 \mathrm{M} \mathrm{NaCl}, 40 \mathrm{mM}$ imidazole and $6 \mathrm{M}$ urea). Recombinant MopB bound to the resin was eluted from the column by using $300 \mathrm{mM}$ imidazole. Recombinant MopB protein was employed to immunize mice by subcutaneous injection at 2 -week intervals. Antiserum was collected after four boosts.

Expression and purification of recombinant endo-1,4- $\beta$ mannanase. The plasmid pET-manA924, carrying a cloned manA gene encoding the mannanase of Xc17, was the kind gift of Dr Yi-Min Hsiao (Central Taiwan University of Science and Technology). Expression and purification of recombinant mannanase was achieved as described by Hsiao et al. (2010). The quantitative endo-1,4- $\beta$ mannanase assay employed the Megazyme procedure, using synthetic azo-carob-galactomannan as the substrate (Megazyme).

Plate assay for hydrolytic activities. To test for cellulase, protease, amylase, pectinase and mannanase activities of Xcc cells, indicator plates were prepared containing XOLN or LB medium supplemented with $0.5 \%(\mathrm{w} / \mathrm{v})$ CM-cellulose, $1 \%(\mathrm{w} / \mathrm{v})$ skimmed milk, $1.5 \%(\mathrm{w} / \mathrm{v})$ soluble starch, $1 \%(\mathrm{w} / \mathrm{v})$ polygalacturonic acid or $0.1 \%(\mathrm{w} / \mathrm{v})$ locust bean gum. Cells were washed and adjusted to an $\mathrm{OD}_{550}$ of 1.0 with $\mathrm{LB}$ medium and $3 \mu \mathrm{l}$ aliquots were spotted onto the plates, followed by incubation at $28{ }^{\circ} \mathrm{C}$ for $48 \mathrm{~h}$. Plates were stained as described previously (Bourgault \& Bewley, 2002; Tang et al., 1991).

Estimation of xanthan polysaccharide levels. The levels of xanthan polysaccharide were measured using a procedure described previously (Fu \& Tseng, 1990), with some modifications. Cells from an overnight culture were harvested by centrifugation and inoculated at an initial $\mathrm{OD}_{550}$ of 0.35 into XOLN medium containing $2 \%(\mathrm{w} / \mathrm{v})$ glucose. After $72 \mathrm{~h}$, cultures were diluted 2- to 10-fold with distilled water and centrifuged at $12000 \mathrm{~g}$ for $20 \mathrm{~min}$ to remove cells. The xanthan polysaccharide in the supernatant was precipitated by addition of $\mathrm{NaCl}$ to $40 \mathrm{mM}$ and ethanol to $70 \%(\mathrm{v} / \mathrm{v})$ and overnight incubation at $-20{ }^{\circ} \mathrm{C}$. The suspension was centrifuged at $20000 \mathrm{~g}$ for $30 \mathrm{~min}$. The pellet was washed once with $70 \%(\mathrm{v} / \mathrm{v})$ ethanol and resuspended in distilled water. Xanthan levels were determined using 
a modified anthrone method (Lin \& Tseng, 1979) and calculated with reference to a standard curve constructed using purified xanthan polysaccharide.

Pathogenicity test. To test for pathogenicity of Xcc, 2-week-old potted cabbage seedlings (variety Big Star; Known-You Seed Co., Kaohsiung, Taiwan) were used in a procedure that has been described previously (Yang \& Tseng, 1988). Leaves to be inoculated were wounded by cutting (length of cut approx. $1 \mathrm{~cm}$ ) with a pair of scissors at the edge at an angle of about 45 degrees to the midrib. Bacterial cells from an overnight culture were diluted 50-fold into fresh $\mathrm{LB}$ broth and grown to an $\mathrm{OD}_{550}$ of 1.0. Aliquots $(10 \mu \mathrm{l})$ of each culture were inoculated by spreading onto the cut surfaces. Infected seedlings were kept in a growth chamber at $28{ }^{\circ} \mathrm{C}$ with constant illumination. Lesions on leaves were observed until 14 days postinoculation for each strain tested. Testing was conducted in three independent experiments, each with six replicates.

Assays of abiotic and biotic adhesion and motility. A quantitative assay for adhesion of Xcc strains was performed as described previously (Chao et al., 2008; Jackson et al., 2002). Cells from overnight cultures $\left(100 \mu \mathrm{l}\right.$ aliquots, $\left.\mathrm{OD}_{550} 1.0\right)$ were inoculated into $3.0 \mathrm{ml}$ XOLN medium [containing $2 \%(\mathrm{w} / \mathrm{v})$ glucose] in $20 \mathrm{ml}$ Universal tubes (QingFa) and incubated with shaking at $28{ }^{\circ} \mathrm{C}$ for $24 \mathrm{~h}$. Cells that bound to the glass surface were measured by removing the medium, rinsing the tubes with $3 \mathrm{ml}$ distilled water (three times) and staining bound cells with $2 \mathrm{ml} 0.3 \%(\mathrm{w} / \mathrm{v})$ crystal violet (Bio Star). The free dye was removed and the tubes were rinsed three times with distilled water. Next, bound crystal violet was solubilized in $1 \mathrm{ml} 33 \%(\mathrm{v} / \mathrm{v})$ acetic acid and the $A_{630}$ was determined using a Hitachi U-1900 spectrophotometer.

The procedures used for the biotic adhesion assay were as described by Rigano et al. (2007) with some modifications. Cabbage leaf discs of approximately $3.8 \mathrm{~cm}^{2}$ were cut from healthy leaves and placed in a flask, to which $30 \mathrm{ml}$ bacterial cells in XOLN medium containing $2 \%$ (w/v) glucose at $\mathrm{OD}_{550}$ of 0.1 was added, and incubated at $28{ }^{\circ} \mathrm{C}$. After 3,12 and $24 \mathrm{~h}$ of incubation, the leaf discs were rinsed gently three times with distilled water. Adherent bacteria on the leaf surface were warmed at $60{ }^{\circ} \mathrm{C}$ for $20 \mathrm{~min}$ and stained with $3 \mathrm{ml} 0.30 \%(\mathrm{w} / \mathrm{v})$ crystal violet for $45 \mathrm{~min}$ at room temperature. The leaf discs were then washed gently three times with distilled water to remove unbound dye. Cells attached to the leaf surface were analysed macroscopically by the intensity of the blue dye.

Motility of Xcc cells was assayed by a method described previously (Lee et al., 2003). Cells from overnight cultures were washed and diluted with $\mathrm{LB}$ medium to an $\mathrm{OD}_{550}$ of 1.0 and $3 \mu \mathrm{l}$ aliquots of cells were inoculated onto XOLN plates containing 0.3 or $0.5 \%(\mathrm{w} / \mathrm{v})$ agar to test for swimming and swarming motility, respectively. Motility was assessed qualitatively by measuring the diameter of the circular halo formed by bacterial cells on plates incubated at $28{ }^{\circ} \mathrm{C}$ for 3 days.

Electron microscopy. Bacteria incubated in LB broth were washed with PBS and fixed overnight with $2 \%(\mathrm{w} / \mathrm{v})$ glutaraldehyde, $4 \%(\mathrm{v} /$ v) paraformaldehyde and $1 \%(\mathrm{w} / \mathrm{v})$ tannic acid in $0.1 \mathrm{~mol}$ cacodylate buffer $1^{-1}, \mathrm{pH}$ 7.4. After washing with PBS, cells were stained and prepared as described by Lin et al. (2007). Treated cells were viewed in a JEOL T300 electron microscope.

\section{RESULTS}

\section{MopB is highly conserved in Xanthomonas}

In the nearly completed genomic sequence of Xcc strain 17 (Xc17), the model strain used in our laboratory, a gene has been assigned as encoding MopB (the major OMP; http:// xcc.life.nthu.edu.tw/). The MopB protein deduced from the gene (1098 bp) contains 365 amino acids, with an Nterminal signal peptide of 22 amino acids. Removal of the signal peptide would produce a mature protein of $37268 \mathrm{Da}$ with a pI of 4.50 .

Complete genome sequences are available for three strains of Xcc. Our sequence comparison indicated that the Xc17 MopB was identical in both size and amino acid sequence to MopBs from all sequenced Xcc genomes (GenBank accession numbers NP_636321, YP_244364 and YP_001904823). The Xc17 MopB was closely related (more than $97 \%$ identity) to MopB from other members of Xanthomonas, including Xanthomonas axonopodis pv. citri 306 (NP 641359), X. campestris pv. vesicatoria 85-10 (YP_362773), X. oryzae pv. oryzicola BLS256 (ZP_02242092) and X. oryzae pv. oryzae strains PX099A and MAFF 311018 (YP_ 001915346 and BAE70245). The Xc17 MopB showed a high level of identity with homologues from Stenotrophomonas maltophilia R551-3 and K279a (87\%; YP_002027188 and YP_001970833) and four strains of Xylella fastidiosa (6871\%; NP_297633, NP_779898, YP_001776390 and YP_ 001830479). Xc17 MopB shared lower degrees of identity with (i) OprF from strains of Pseudomonas, including Pseudomonas putida KT2440 and GB-1, P. syringae pv. tomato DC3000, P. syringae pv. phaseolicola 1448A and $P$. aeruginosa PA01 (28-30\%; NP_744239, YP_001667841, NP_792118, YP_274287 and NP_250468); (ii) OmpF from strains of Pseudomonas, including P. putida W619 and $P$. fluorescens Pf0-1 (29.3-29.8\%; YP_001748481 and YP_ 347509); (iii) thrombospondin type 3 repeat from Nautilia profundicola $\mathrm{AmH}, P$. syringae pv. syringae B728a and Azotobacter vinelandii AVOP (24-28\%; YP_002606840, YP_235178 and ZP_00415173); (iv) Tbd0127 from Thiobacillus denitrificans ATCC 25259 (28.2\%; YP_313885); (v) MopB from Methylococcus capsulatus Bath (28.1\%, YP_ 115490); (vi) outer-membrane fibronectin-binding protein from Campylobacter fetus subsp. fetus 82-40 and Arcobacter butzleri RM4018 (27\%; YP_891591 and YP_001489425); and (vii) E. coli APECO1 OmpA (21\%, YP_852080). Notably, among these homologues of Xcc MopB, only E. coli OmpA has been shown to be involved in pathogenesis (Khan et al., 2003; Wang, 2002). A phylogenetic tree constructed on the basis of multiple sequence alignment reflected the evolutionary relationships among these homologous proteins (Fig. 1). Notably, the relatedness among MopB homologues, displayed by the phylogenetic tree, was similar to that of the 16S rRNA gene (not shown).

Our sequence analysis also showed that these MopB homologues, belonging to the OmpA family, each had an OmpA domain $\mathrm{NX}_{2} \mathrm{LSX}_{2} \mathrm{RAX}_{2} \mathrm{VX}_{3} \mathrm{~L}$ (de Mot \& Vanderleyden, 1994a) and a calcium-binding motif DxDxDG (de Mot \& Vanderleyden, 1994b; Rigden \& Galperin, 2004), located in Xc17 MopB at aa 301-316 and aa $216-221$, respectively. 


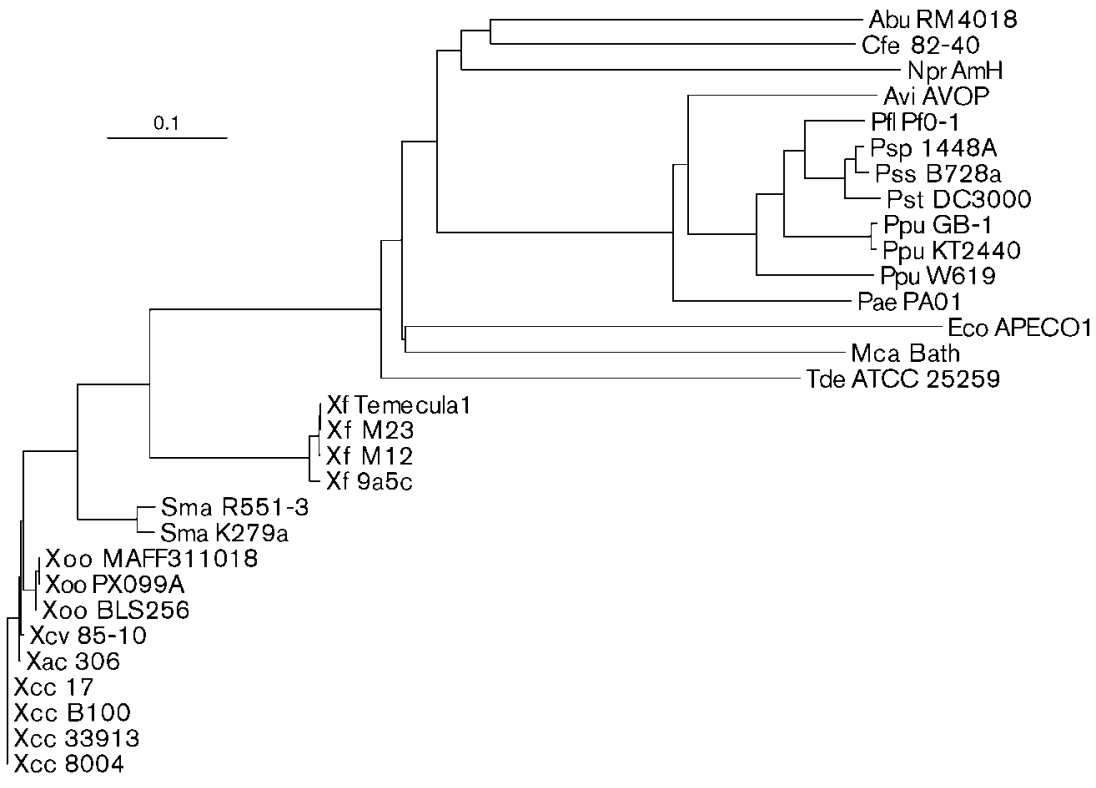

Fig. 1. Phylogenetic relationships between outer-membrane proteins MopB from xanthomonads and related genera. Abu, Arcobacter butzleri; Avi, Azotobacter vinelandii; Cfe, Campylobacter fetus subsp. fetus; Eco, Escherichia coli; Mca, Methylococcus capsulatus; Npr, Nautilia profundicola; Pae, Pseudomonas aeruginosa; Pfl, Pseudomonas fluorescens; Ppu, Pseudomonas putida; Psp, Pseudomonas syringae pv. phaseolicola; Pss, Pseudomonas syringae pv. syringae; Pst, Pseudomonas syringae pv. tomato; Sma, Stenotrophomonas maltophilia; Tde, Thiobacillus denitrificans; Xac, Xanthomonas axonopodis pv. citri; Xcc, Xanthomonas campestris pv. campestris; Xcv, Xanthomonas campestris pv. vesicatoria; Xoo, Xanthomonas oryzae pv. oryzae; Xf, Xylella fastidiosa.

\section{MopB is the most abundant OMP in Xc17, and a MopB deficiency causes changes in the OMP composition}

For further study of the $m o p B$ gene, a mopB mutant (XcMopB) was constructed. This mutant and the parental Xc17 were used for comparison of OMP profiles and to verify that MopB was indeed the major OMP. Membrane fractionation was based on the differential solubility of the inner membrane (IM) and OM in Sarkosyl $(0.25 \%$, w/v), with the former being soluble and the latter insoluble in the detergent solution. Following fractionation, samples were subjected to separation by SDS-PAGE, followed by detection of MopB with antibodies prepared by immunizing mice with a recombinant MopB expressed in E. coli. To demonstrate the efficiency of fractionation in these experiments, the same samples were treated in parallel and probed with antibodies prepared against $\mathrm{Xc17}$ superoxide dismutase (SOD), a protein that is confined to the cytosol. The results indicated that the SOD protein was indeed detected only in crude extracts and in fractions containing cytoplasmic and periplasmic proteins (not shown).

As shown in Fig. 2(a), the OM fraction from Xc17 displayed more than 10 distinct protein bands upon staining of gels with Coomassie brilliant blue, with a $37 \mathrm{kDa}$ protein being the most abundant (lane 4). This molecular size was similar to that of MopB reported for Xcc strains 528 and 1648 (Ojanen et al., 1993) and to that calculated from the amino acid sequences of MopB predicted from Xanthomonas genomes. In the OM fraction of the mopB mutant, the $37 \mathrm{kDa}$ band was missing, and more than 17 protein bands were observed, of which five were too faint to be visible in wild-type Xc17 (Fig. 2a, lanes 4 and 5). These results indicated that the OMP profile was altered by mutation of mopB. Western-blot results showed that most of the $37 \mathrm{kDa}$ protein of $\mathrm{Xc17}$ was localized in the OM fraction, and only very small amounts were seen in other fractions (Fig. 2b, lanes 1-4). No corresponding hybridization signal was observed from the $\mathrm{OM}$ fraction prepared from XcMopB (Fig. 2b, lane 5), confirming that insertional mutation had destroyed expression of the mopB gene. These data together indicated that MopB, being the most abundant protein, was the major OMP of Xcc.

\section{Mutation in Xcc mopB causes loss of pathogenicity}

Xcc is an important plant pathogen and its pathogenicity has been the focus of our research. To determine whether mutation of $\operatorname{mop} B$ caused loss of pathogenicity, XcMopB was used to infect cabbage seedlings. In these tests, the tissue around the leaf margin where Xc17 cells had been inoculated turned yellow at about 4 days after infection and then, at day 6, V-shaped chlorotic lesions began to spread from the leaf margin toward the midrib. The progression of symptom development in the complemented strain, $\mathrm{XcMopB}(\mathrm{pRK}-m o p B)$, was similar to that of Xc17. Fig. 3 shows the symptoms caused by wild-type Xc17 and the complemented strain at 10 days after inoculation. However, no symptoms were visible on leaves inoculated with $\mathrm{XcMopB}$, even after prolonged incubation for more than 14 days (Fig. 3). These results demonstrate clearly that XcMopB had lost the ability to cause black rot in cabbage.

\section{XcMopB forms aggregates when cultures enter stationary phase and is more sensitive to stressful conditions than is the parental strain}

During characterization of the mutant XcMopB, the effects of the mutation on bacterial growth were evaluated and several defects were identified. 
(a)

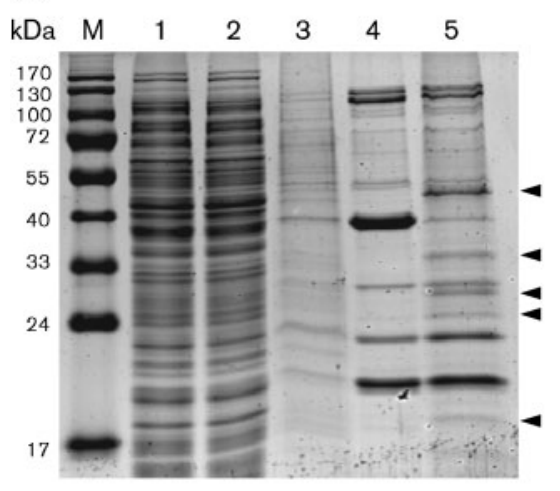

(b)

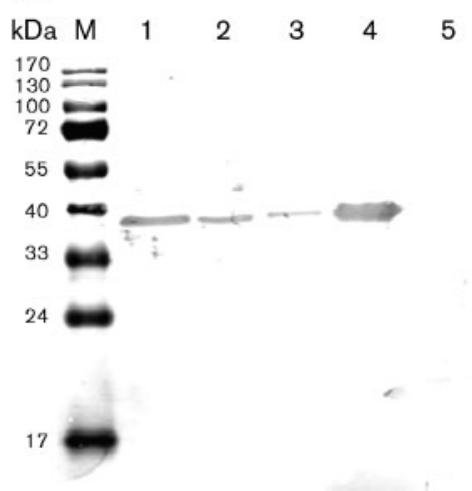

Fig. 2. Identification of MopB as the major OMP of $X_{c} 17$ by Western blotting. Membrane fractions were prepared from wild-type $X_{c} 17$ and the mopB mutant $\mathrm{XcMopB}$ by treatment with $0.25 \%(\mathrm{w} / \mathrm{v})$ Sarkosyl and separated into detergent-soluble (IM) and -insoluble (OM) fractions. Proteins from each fraction were separated on $12 \%(\mathrm{w} / \mathrm{v})$ SDS-polyacrylamide gels (a) followed by Western blotting using polyclonal antibodies against MopB (1:100 000) (b). Lanes: $M$, size markers; 1 , Xc17 crude extract; 2, cytoplasm and periplasm of Xc17; 3, Xc17 IM; 4, Xc17 OM; 5, XcMopB OM. Arrowheads indicate bands in the XcMopB OM that were not observable in the $\mathrm{Xc17}$ OM. (i) XcMopB forms cell aggregates. As soon as XcMopB was isolated, we noticed that cells formed aggregates after overnight incubation, although bacteria of the parental Xc17 strain remained dispersed. XcMopB cells grew at the same rate as the wild-type strain before entering stationary phase (i.e. prior to $14 \mathrm{~h}$ ) and both reached an $\mathrm{OD}_{550}$ of about 3.7. The $\mathrm{OD}_{550}$ of $\mathrm{Xc17}$ continued to increase slightly until saturation $\left(\mathrm{OD}_{550} 4.4\right)$ at $22 \mathrm{~h}$, whereas $\mathrm{XcMopB}$ cultures ceased to grow at $14 \mathrm{~h}$ and began to decrease in bacterial numbers (as detected by colony counting) at $16 \mathrm{~h}$ owing to formation of cell aggregates (Fig. 4). To estimate

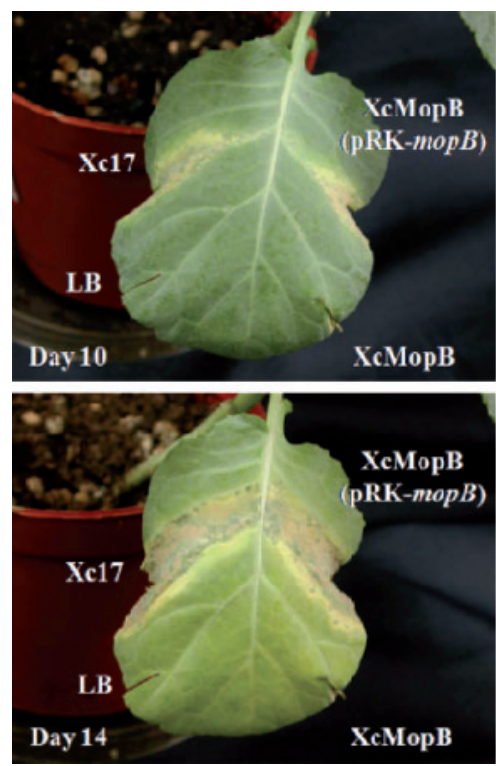

Fig. 3. Pathogenicity of $X_{c c}$ strains. Cells (about $5 \times 10^{6}$ cells in $10 \mu \mathrm{l})$ of the wild-type $\mathrm{Xc17}_{\mathrm{c}}$, the mopB mutant (XcMopB) and the complemented strain $\mathrm{XcMopB}(\mathrm{pRK}-m o p B)$ were inoculated into cuts on the edges of leaves of 2-week-old potted cabbage plants. Appearance of symptoms was recorded on days 10 and 14 postinoculation. LB, LB broth used as a control. the proportion of cells in aggregates, cultures were filtered through Whatman No.1 filter paper (55-mm diameter discs) and the $\mathrm{OD}_{550}$ of the filtrates was measured. The results indicated that the $\mathrm{OD}_{550}$ of the $\mathrm{XcMopB}$ culture was reduced to about $69.5 \%$ that of wild-type cells (Fig. 4), indicating that more than $30 \%$ of the cells had become aggregated.

(ii) Aggregate formation by the $\operatorname{mop} B$ mutant and an rpfF mutant involves different mechanisms. Xcc $r p f F$ mutant cells, which are deficient in the synthesis of DSF, become aggregated when cultures enter stationary phase and synthesize a gum-like substance that forms a thick

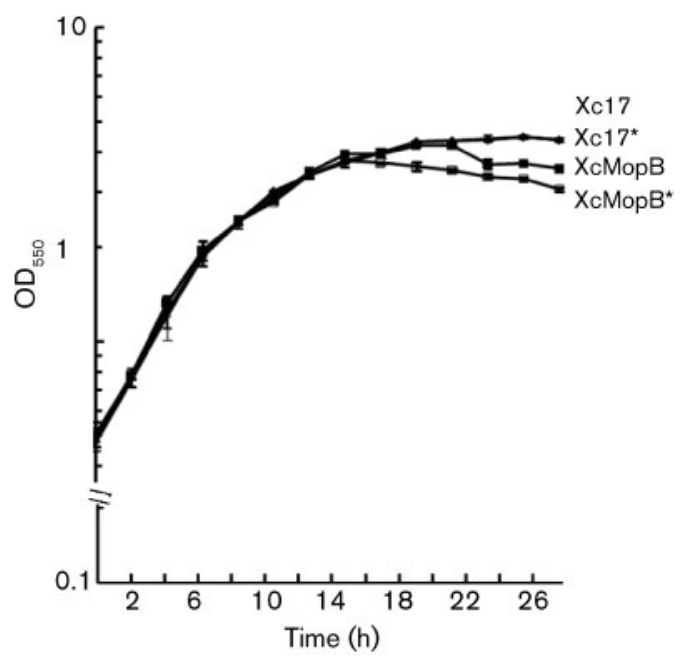

Fig. 4. Growth of $X c c$ strains in LB medium. Cells of the wild-type $\mathrm{Xc}_{\mathrm{c} 17}$ and $\mathrm{XcMopB}$ were diluted into $30 \mathrm{ml} \mathrm{LB}$ medium to $\mathrm{OD}_{550}$ 0.35 and grown at $28{ }^{\circ} \mathrm{C}$. The $\mathrm{OD}_{550}$ was monitored during growth. After cultures entered stationary phase, duplicate samples were taken and one set (indicated by asterisks) was filtered prior to reading of $O D_{550}$ to estimate the proportion of cells in aggregates; the other sample was read directly. 
layer on the top of pelleted cells after centrifugation; addition of either DSF or purified endo- $\beta$-1,4-mannanase encoded by manA of the same bacterium can disperse the aggregates (Dow et al., 2003). In the present study, to compare aggregate properties, cultures of XcMopB and the $r p f F$ mutant were grown in parallel. As shown in Fig. 5(a), cells of Xc17 remained dispersed throughout growth (flask 1 ); in contrast, XcMopB formed conspicuous clumps and sedimentation of cells was observed after $24 \mathrm{~h}$ (Fig. 5a, flask 2). The aggregate-forming phenotypes of the mopB and $r p f F$ mutants were found to be similar, except that the clumps of XcMopB were larger (Fig. 5a, flask 2; Fig. 5b, flask 2). No visible gummy substance was produced by Xc17, with no obvious layer seen on the top of pelleted cells after centrifugation $(10000 \mathrm{~g}, 10 \mathrm{~min})$ of $24 \mathrm{~h}$ cultures (Fig. 5c, tube 1); in contrast, a thick layer of gummy substance was found over the top of pelleted XcMopB (Fig. $5 c$, tube 2) and rpfF mutant (Fig. $5 \mathrm{~d}$, tube 2 ) cells. The pelleted gummy substance from the mopB mutant was more compact than that of the $r p F$ mutant, indicating that the texture and composition of these two types of gummy substance were not the same. Addition of synthetic DSF (final concentration, $10 \mu \mathrm{M}$ ) at $16 \mathrm{~h}$ of growth could disperse $r p f F$ mutant cells $8 \mathrm{~h}$ after treatment (Fig. 5b, flask 3 ), but the same addition did not disperse XcMopB cells (Fig. 5a, flask 3 ). When purified endo- $\beta-1,4$-mannanase $(5 \mathrm{mU})$ was added to cultures after $16 \mathrm{~h}$ of growth, the aggregates formed by the rpfF mutant were dispersed at $0.5 \mathrm{~h}$ after the treatment (Fig. 5b, flask 4), but XcMopB aggregates were not dispersed (Fig. 5a, flask 4). Furthermore, treatments that blocked formation of the gum-like substance by the $r p f F$ mutant effectively (Fig. $5 \mathrm{~d}$, tubes 3 and 4) could not inhibit formation of the gummy substance found in the XcMopB cultures (Fig. 5c, tubes 3 and 4). These results indicate that, although the phenotypes of the aggregates were similar, both the mechanisms involved in aggregate formation and the chemical nature of the gummy substances differed.

A dispersed growth mode, similar to that of Xc17, was restored to the complemented strain by provision of the cloned wild-type mopB gene (Fig. 5a, flask 5). No gummy substance was observed on the top of pelleted complemented cells (Fig. 5c, tube 5). These results confirmed that deficiency in MopB was indeed the factor causing cell aggregation.

(iii) XcMopB cannot grow at $37^{\circ} \mathrm{C}$. For temperaturesensitivity tests, cells were grown at either $28^{\circ} \mathrm{C}$, the normal temperature for Xcc growth, or $37{ }^{\circ} \mathrm{C}$. At $28{ }^{\circ} \mathrm{C}$, $\mathrm{XcMopB}$ grew at a similar rate to wild-type $\mathrm{Xc17}$, as has been shown above (Fig. 4). When the temperature was increased to $37{ }^{\circ} \mathrm{C}$, the growth rate of $\mathrm{Xc17}$ was reduced markedly, and no significant growth of $\mathrm{XcMopB}$ was observed (Fig. 6a).

(iv) $\mathrm{XcMopB}$ cannot grow at $\mathrm{pH}$ higher than 8.5. To test for effects of $\mathrm{pH}$ on growth of the mopB mutant, cells were (a)

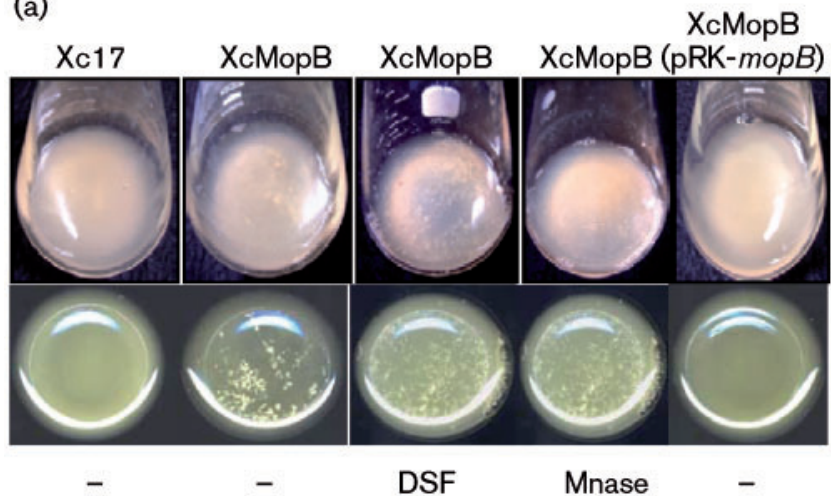

(b)

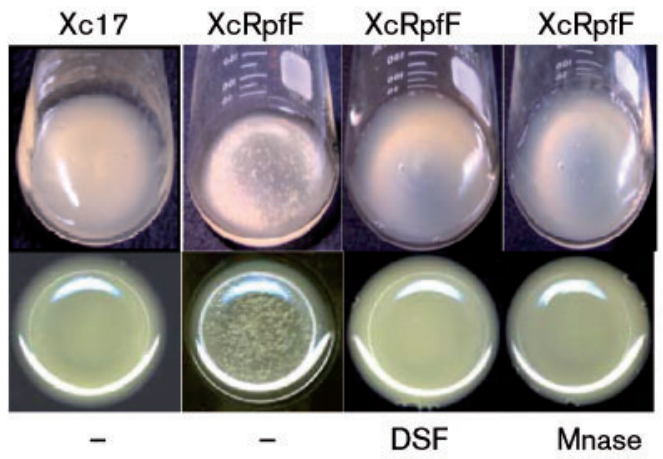

(c)

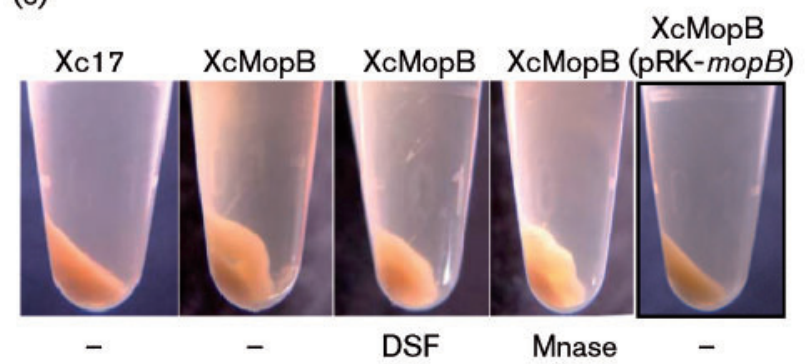

(d)

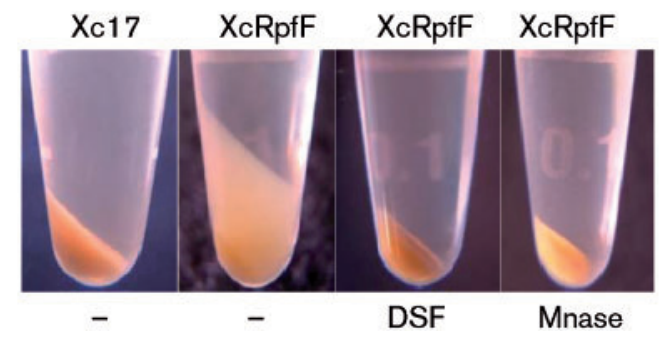

Fig. 5. Aggregate formation and dispersal by $X c c$ strains. (a) Cells of $X_{c} 17$, the mopB mutant $X_{c} M o p B$ and the complemented strain $\mathrm{XcMopB}\left(\mathrm{pRK}-m o p B\right.$ ) were grown in $\mathrm{LB}$ at $28^{\circ} \mathrm{C}$ for $16 \mathrm{~h}$ and treated by addition of DSF (final concentration, $10 \mu \mathrm{M}$ ), purified endo- $\beta$-1,4-mannanase (5 mU; Mnase) or LB medium (-). Photographs were taken $8 \mathrm{~h}$ after treatment. (b) Cells of $X_{c} 17$ and the rpfF mutant were treated as described in (a). (c, d) Microcentrifuge tubes containing pelleted cells of cultures from the flasks of (a) and (b), respectively. In (a) and (b), the upper photographs in each pair were taken from the front, whereas the lower ones were taken from below. 
(a)

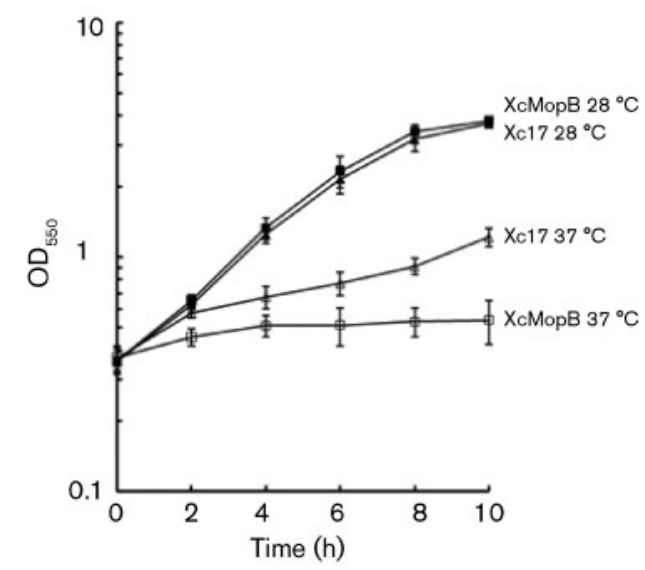

(b)

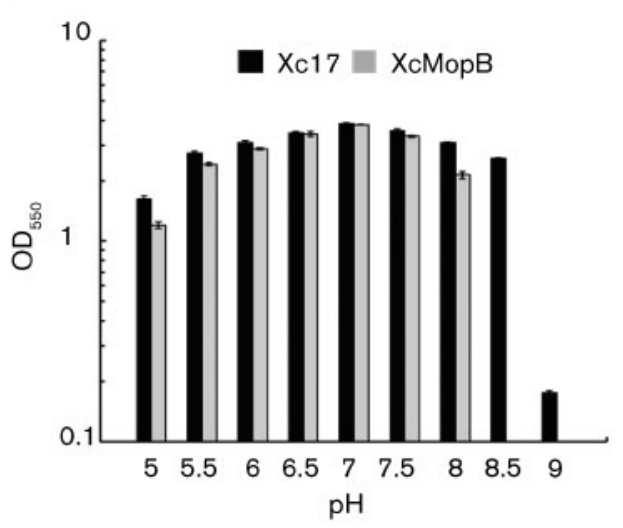

(c)

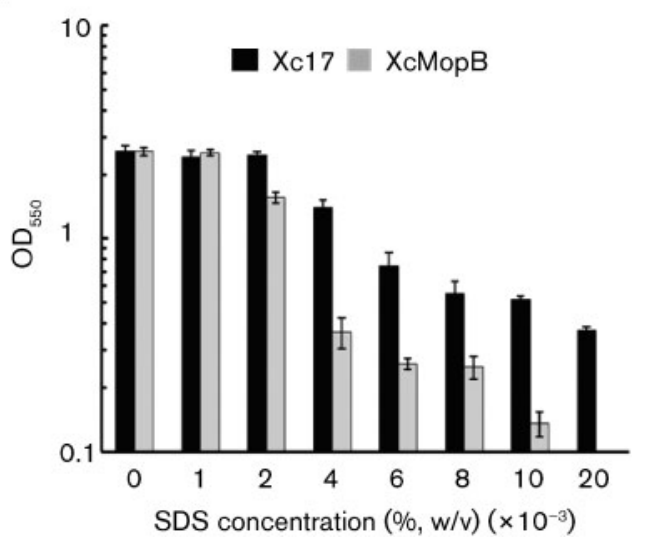

grown at different $\mathrm{pH}$ values after adjustment with citrate buffer. As shown in Fig. 6(b), both the mopB mutant and the parental $\mathrm{Xc17}$ strain showed the best growth at $\mathrm{pH} 7.0$, but, when the $\mathrm{pH}$ was varied, different levels of growth inhibition were observed. At $\mathrm{pH} 8.5$, no significant growth of the mopB mutant was detected, whereas growth of $\mathrm{Xc17}$ was about $67 \%$ of that seen at $\mathrm{pH} 7.0$.

(v) XcMopB is more sensitive to SDS. It was found that $\mathrm{Xc17}$ was able to tolerate SDS at $0.002 \%(\mathrm{w} / \mathrm{v})$, but the
Fig. 6. Growth of $X_{c c}$ strains under stressful conditions. Overnight cultures of $X_{c} 17$ and $X_{c} M o p B$ were diluted into $30 \mathrm{ml}$ LB medium to $\mathrm{OD}_{550}$ 0.35. (a) Cells were grown at 28 or $37{ }^{\circ} \mathrm{C}$ to test for tolerance to elevated temperature. Growth of cells was monitored by reading of $\mathrm{OD}_{550}$. (b) The $\mathrm{pH}$ of the $\mathrm{LB}$ medium was adjusted by addition of citrate buffer and growth was measured $16 \mathrm{~h}$ later. (c) SDS at different concentrations was added to the medium and growth of cells was measured $8 \mathrm{~h}$ later.

final yield of cells decreased with increasing SDS concentration (Fig. 6c). Tolerance of the mopB mutant to SDS decreased markedly with increasing concentrations of SDS, and no cell growth was detectable when the concentration was increased to $0.02 \%(\mathrm{w} / \mathrm{v})$, whereas $\mathrm{Xc17}$ still produced about $15 \%$ of the maximum cell yield.

\section{EPS production is impaired in the XcMopB strain}

Colonies of XcMopB were less mucoid on either LB or XOLN agar containing glucose, compared with colonies of wild-type Xc17. Formation of non-mucoid colonies suggested that $\mathrm{XcMopB}$ produced less EPS xanthan gum than did the wild-type strain. To assess the ability of $\mathrm{XcMopB}$ to produce EPS, Xcc cells were grown in XOLN medium containing $2 \%(\mathrm{w} / \mathrm{v})$ glucose for $72 \mathrm{~h}$ and EPS contents in culture supernatants were measured. The results indicated that XcMopB produced about $2044 \pm$ $140 \mu \mathrm{g}$ EPS $\mathrm{ml}^{-1}$, approximately $58 \%$ of that produced by wild-type Xc17 $\left(3242 \pm 203 \mu \mathrm{g} \mathrm{ml}^{-1}\right)$. The complemented strain, XcMopB(pRK-mopB), produced $2849 \pm 256 \mu \mathrm{g}$ EPS $\mathrm{ml}^{-1}$, about $90 \%$ of that produced by Xc17. These results indicate that the ability to synthesize EPS was impaired by mutation of the mopB gene.

Extracellular enzymes, in addition to EPS, have been implicated as virulence factors (Chan \& Goodwin, 1999; Chou et al., 1997; Dharmapuri \& Sonti, 1999; Dow et al., 2003; Katzen et al., 1998); hence, the hydrolytic activities of XcMopB were assayed on XOLN and LB agar plates containing skimmed milk, CM-cellulose, pectin, mannan or starch. No significant differences were found between the parental $\mathrm{Xc17}$ and $\mathrm{XcMopB}$.

\section{Mutation in mopB causes a drastic change in cell- surface properties and reductions in adhesion and motility}

The formation of cell aggregates by XcMopB and associated changes in OMP composition indicated that significant alterations might have occurred on the cell surface. To investigate this, cross-sections of Xcc cells were prepared and subjected to electron microscopic observation. The results showed that cells of wild-type Xc17 displayed an electron-dense cytoplasm, a less-dense IM and a surface OM (Fig. 7a). These layers were in intimate contact. In contrast, the OM of the $m o p B$ mutant appeared less compact and was deformed, with a wide electron-transparent 
(a)

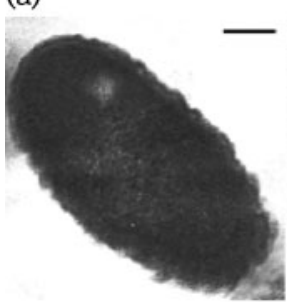

(b)

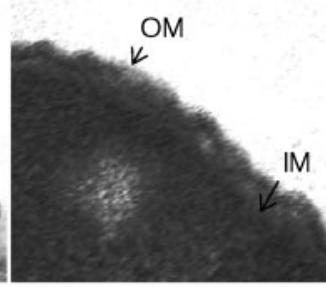

(c)

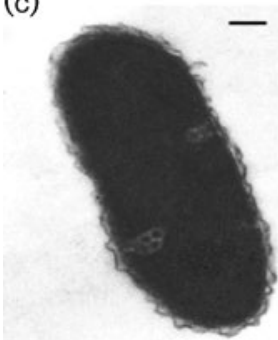

(e)

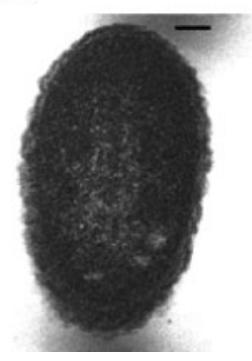

(d)

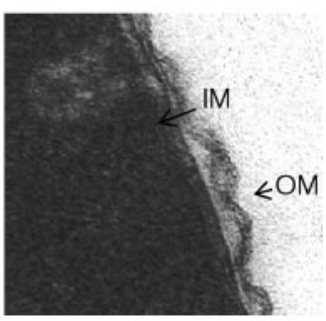

(f)

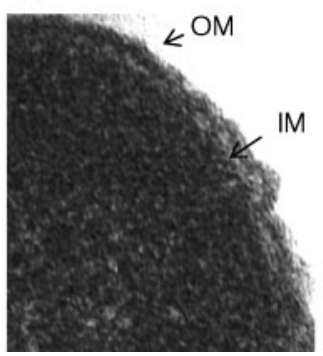

Fig. 7. Electron microscopy of Xcc strains. Cells of the wild-type $\mathrm{Xc}_{\mathrm{c}} 7$ (a), the mopB mutant $\mathrm{XcMopB}$ (c) and the complemented strain XcMopB(pRK-mopB) (e) were treated as described in Methods. (b), (d) and (f) are enlargements from (a), (c) and (e), respectively. Bars, $100 \mathrm{~nm}$.

region that probably represents an enlarged periplasmic space (Fig. 7b). The complemented strain had a surface structure similar to that of wild-type cells (Fig. 7c). These data indicated that mutation in Xcc mopB led to marked changes in the OM, leading to a looser connection between the IM and OM.

After determining that the outer layers of XcMopB bacteria had been altered markedly by mutation, we investigated whether the adhesion and motility properties of XcMopB were affected. Adhesion to a glass surface was assayed quantitatively by the crystal violet staining method. The results showed that, although wild-type Xc17, mutant $\mathrm{XcMopB}$ and the complemented strain XcMopB(pRK$m o p B$ ) exhibited similar growth rates under our assay conditions, the mutant cells had reduced adhesion ability. The $A_{630}$ measured in samples prepared from XcMopB cells was approximately 0.16 , which was about $34 \%$ that of Xc17 $\left(A_{630} 0.47\right)$; about $85 \%$ of adhesion ability was restored by complementation (Fig. 8a). Bacterial adhesion to cabbage leaves was tested according to the procedures described by Rigano et al. (2007) with some modifications.
The results showed that the number of attached bacteria was significantly greater on discs inoculated with $\mathrm{Xc17}$ and $\mathrm{XcMopB}(\mathrm{pRK}-m o p B)$ than the mutant after $12 \mathrm{~h}$ of incubation, and the difference became even more obvious after $24 \mathrm{~h}$ (Fig. 8b).

Swimming and swarming were tested by inoculating Xcc cells into XOLN medium containing 0.3 and $0.5 \%(\mathrm{w} / \mathrm{v})$ agar, respectively. The colony diameters of $\mathrm{Xc17}$ and XcMopB strains were about 16.6 and $12.4 \mathrm{~mm}$ in the swimming mode and 17.8 and $12.0 \mathrm{~mm}$ when swarming was permitted, respectively, 25 and $34 \%$ less than exhibited by wild-type cells.

\section{DISCUSSION}

In the present study, bioinformatic analysis revealed that protein XCC0935 in the nearly completed genomic sequence of $\mathrm{Xc17}$ was annotated as MopB, the major OMP B. Identification of this protein as the major OMP (the most abundant OMP) was confirmed by SDS-PAGE followed by Western blotting of OM fractions, in which a MopB band of $37 \mathrm{kDa}$, similar to the size predicted from the nucleotide sequence, was absent from the XcMopB strain constructed by insertional mutation and restored in a complemented strain providing the cloned wild-type mopB gene in trans. Previous SDS-PAGE analysis of OMPs from $X$. campestris showed that, although heterogeneity in OMP profiles existed within individual pathovars, a $37 \mathrm{kDa}$ protein was consistently the most abundant in isolates of Xcc (Ojanen et al., 1993). These findings are consistent with our bioinformatic analysis showing that MopB is highly conserved among members of Xanthomonas. The Xcc MopB also has high identity with MopBs from members of the related genera Stenotrophomonas $(>86.7 \%)$ and Xylella $(>68.4 \%)$, but showed a low level of identity with OprF of $P$. aeruginosa (30.3\%) and OmpA of E. coli $(20.8 \%)$.

Mutation in the Xcc mopB gene resulted in a marked alteration in both the composition and architecture of the OM. In our SDS-PAGE analysis, at least five OMPs were shown to be abundant in the mutant; these proteins were too faint to be visible in samples prepared from wild-type Xc17, indicating that mutation in $m o p B$ caused alterations in the OMP profile and probably increased expression of some otherwise minor OMPs. A similar situation was found in a mutant deficient in OmpJ, a putative porin required for metal respiration of Geobacter sulfurreducens; marked changes in the amounts of several proteins, including a membrane-associated cytochrome, were observed (Afkar et al., 2005). Further studies are needed to identify these proteins in Xcc and to elucidate the significance of the change in their amounts. The changes in OMP composition of the mopB mutant were accompanied by deformation of the mutant surface, as revealed by electron microscopy. The marked change in the surface layer is probably the reason for the multiple defects observed in 
(a)

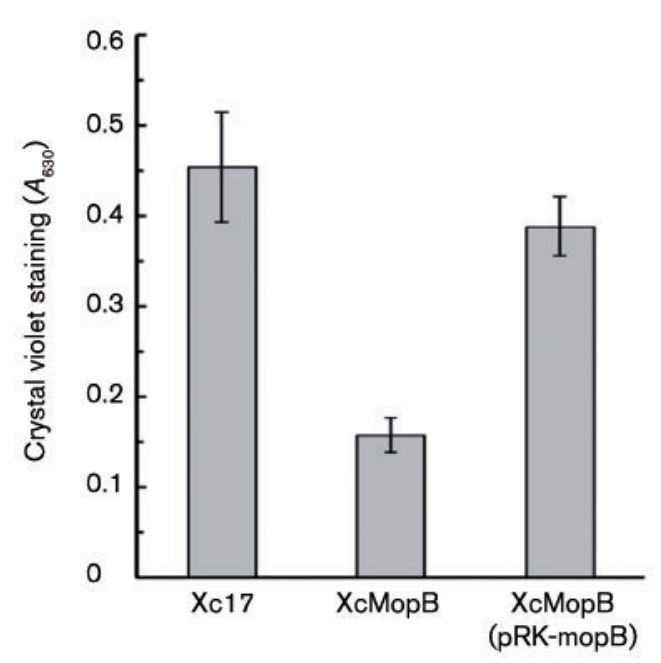

(b)
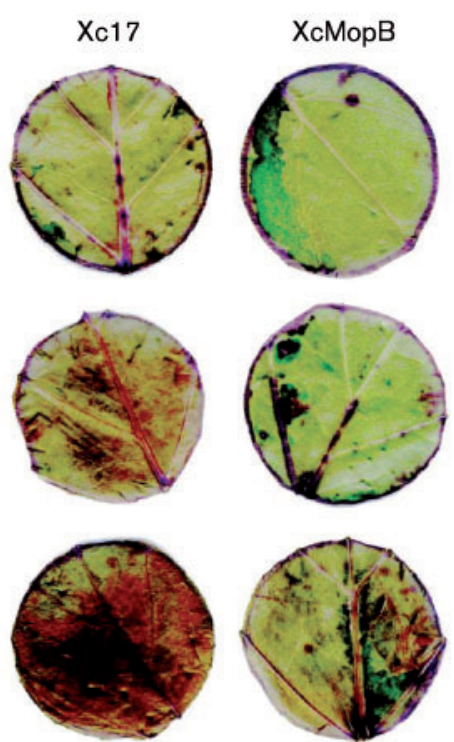
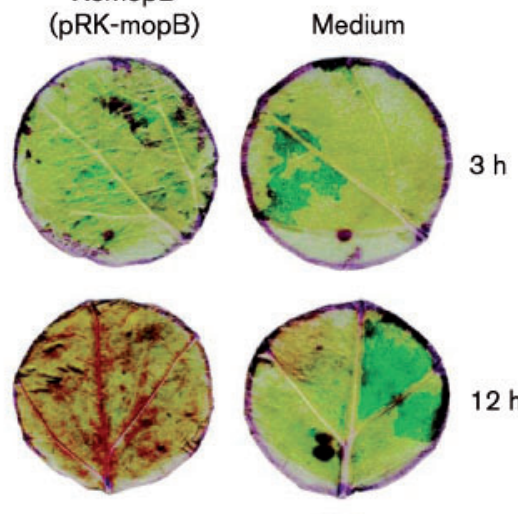

$12 \mathrm{~h}$
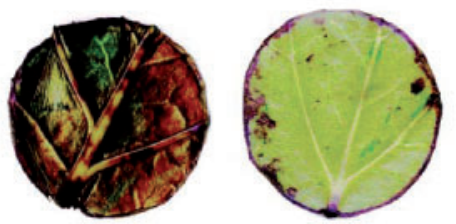

Fig. 8. Adhesion test of $X c c$ strains. (a) Overnight culture $\left(100 \mu\right.$ l aliquots, $\left.O D_{550} 1.0\right)$ samples of each strain were inoculated into $3.0 \mathrm{ml} \mathrm{XOLN} \mathrm{medium} \mathrm{[supplemented} \mathrm{with} 2 \%(\mathrm{w} / \mathrm{v})$ glucose] in $20 \mathrm{ml}$ Universal tubes and incubated at $28{ }^{\circ} \mathrm{C}$ for $24 \mathrm{~h}$. Samples were treated as described in Methods, followed by measurement of the amount of bound crystal violet. (b) Bacterial adhesion to cabbage leaves was assayed by staining the attached bacterial cells with crystal violet at 3,12 and $24 \mathrm{~h}$ postincubation as described in Methods.

XcMopB, including formation of cell aggregates, reduced xanthan production, reduced adhesion and motility, increased sensitivity to stress conditions and loss of pathogenicity.

It is well known that mutations in $\mathrm{Xcc} r p f F$, the gene responsible for the synthesis of DSF, cause formation of cell aggregates when cultures enter stationary phase (Dow et al., 2003). Upon centrifugation of aggregated cultures, a thick layer of gum-like material can be seen on top of pelleted cells. The aggregates can be dispersed by addition of either DSF or an endo- $\beta-1,4$-mannanase encoded by Xcc, indicating that the gum-like substance contains chemical bonds cleavable by endo- $\beta$-1,4-mannanase (Dow et al., 2003). In the mopB mutant, aggregated cells could not be dispersed by addition of either DSF or endo$\beta$-1,4-mannanase, indicating that the gummy substance has a chemical structure different from the gum formed by the $r p f F$ mutant. Thus, it appeared that aggregate formation by the mopB and $r p f F$ mutants involved different mechanisms.

Xcc is capable of producing large amounts of xanthan polysaccharide and an array of extracellular enzymes, which collectively have long been considered important virulence determinants (Chan \& Goodwin, 1999; Chou et al., 1997; Dharmapuri \& Sonti, 1999; Dow et al., 2003; Dums et al., 1991; Yang \& Tseng, 1988). In the present study, we have shown that production of xanthan was impaired by cellular enzymes was not affected. The biosynthesis of xanthan involves synthesis of sugar nucleotide precursors, formation of pentasaccharide repeating units from sugar nucleotides on a glycosyl lipid carrier, acetylation and pyruvylation of some mannose residues, polymerization of the pentasaccharide repeating units and secretion of the polymeric molecules (Katzen et al., 1998; Vorholter et al., 2008). Proteins involved in xanthan synthesis, except those involved in formation of sugar nucleotides, are encoded by the gum operon containing gumB to gumM. Functions of particular proteins in repeating unit synthesis (GumDMHKI), acetylation (GumFG) and pyruvylation (GumL) have been confirmed experimentally (Becker et al., 1998; Katzen et al., 1998; Vorholter et al., 2008). In addition, a mechanistic model proposed on the basis of data obtained from genome annotation studies suggested that GumJ flips the lipid carrier-linked pentasaccharide repeating unit to the outer face of the IM, where polymerization is performed by GumE; upon contact with the IM-associated GumC and the OM-associated GumB, a complex periplasm-spanning pore is opened to export the xanthan polymer to the milieu (Vorholter et al., 2008). As the cell surface is greatly deformed, the $\operatorname{mop}_{B}$ mutation may have drastically changed the topology of GumB; without proper positioning of this important protein, the xanthan export machinery will malfunction. It is known that xanthan production is upregulated by DSF and Clp (He et al., 2006, 2007; Slater et al., 2000), but little is known about the roles of other possible regulators. In E. coli K1, expression of type 1 fimbriae, controlled by phase variation, is decreased upon deletion of ompA (Teng et al., 2006). Thus, the possibility exists that, in Xcc, MopB 
regulates the expression of the gum operon via an unidentified mechanism, although phase variation may not necessarily be involved. The pathogenesis of black rot by Xcc involves multiple steps, including at least leaf attachment, epiphytic fitness, entry, colonization, biofilm formation/dispersal and bacterial spread to the vascular system (Chan \& Goodwin, 1999; Dow et al., 2003; Rigano et al., 2007). The consequence of mutation in the Xcc mopB gene is pleiotropic, including formation of cell aggregates, reduction in xanthan production, adhesion and motility and increased sensitivity to stress conditions. Since we have previously shown that a mutation causing reduction in xanthan (about $95 \%$ reduction) resulted in only a delayed appearance of the black rot symptoms and not a complete loss of pathogenicity (Chou et al., 1997), a $42 \%$ reduction in xanthan production is unlikely to be the major reason for the loss of pathogenicity in XcMopB. In addition, as synthesis of extracellular enzymes was not altered in this mutant, the importance of such enzymes in the initial stages of pathogenesis may be limited. Therefore, it seems reasonable to conclude that the loss of pathogenicity in XcMopB may result from a concerted effect of increased sensitivity to stress conditions, which may reduce epiphytic fitness, and aggregate formation and reduction in motility and adhesion, which would affect biofilm formation/ dispersal and limit bacterial colonization and spread. Our findings of pleiotropic effects caused by mutation of the mopB gene, including loss of pathogenicity, may help the development of new strategies for the control of black rot disease.

\section{ACKNOWLEDGEMENTS}

We sincerely thank Dr Hsiao Yi-Min for donating the mannanaseexpressing plasmid pET-manA924. This study was supported by grant NSC-95-2311-B-005-005-MY3 from the National Science Council, Republic of China.

\section{REFERENCES}

Afkar, E., Reguera, G., Schiffer, M. \& Lovley, D. R. (2005). A novel Geobacteraceae-specific outer membrane protein J (OmpJ) is essential for electron transport to $\mathrm{Fe}(\mathrm{III})$ and $\mathrm{Mn}(\mathrm{IV})$ oxides in Geobacter sulfurreducens. BMC Microbiol 5, 41.

Barabote, R. D., Johnson, O. L., Zetina, E., San Francisco, S. K., Fralick, J. A. \& San Francisco, M. J. (2003). Erwinia chrysanthemi tolC is involved in resistance to antimicrobial plant chemicals and is essential for phytopathogenesis. J Bacteriol 185, 57725778.

Becker, A., Katzen, F., Puhler, A. \& lelpi, L. (1998). Xanthan gum biosynthesis and application: a biochemical/genetic perspective. Appl Microbiol Biotechnol 50, 145-152.

Bishop, R. E. (2008). Structural biology of membrane-intrinsic betabarrel enzymes: sentinels of the bacterial outer membrane. Biochim Biophys Acta 1778, 1881-1896.

Bourgault, R. \& Bewley, J. D. (2002). Gel diffusion assays for endobeta-mannanase and pectin methylesterase can underestimate enzyme activity due to proteolytic degradation: a remedy. Anal Biochem 300, 87-93.
Browning, D. F., Whitworth, D. E. \& Hodgson, D. A. (2003). Lightinduced carotenogenesis in Myxococcus xanthus: functional characterization of the ECF sigma factor CarQ and antisigma factor CarR. Mol Microbiol 48, 237-251.

Chan, J. W. \& Goodwin, P. H. (1999). The molecular genetics of virulence of Xanthomonas campestris. Biotechnol Adv 17, 489-508.

Chao, N. X., Wei, K., Chen, Q., Meng, Q. L., Tang, D. J., He, Y. Q., Lu, G. T., Jiang, B. L., Liang, X. X. \& other authors (2008). The $r s m A$-like gene $\operatorname{rsm} A(\mathrm{Xcc})$ of Xanthomonas campestris pv. campestris is involved in the control of various cellular processes, including pathogenesis. Mol Plant Microbe Interact 21, 411-423.

Choi, C. H., Lee, J. S., Lee, Y. C., Park, T. I. \& Lee, J. C. (2008). Acinetobacter baumannii invades epithelial cells and outer membrane protein A mediates interactions with epithelial cells. BMC Microbiol 8, 216.

Chou, F. L., Chou, H. C., Lin, Y. S., Yang, B. Y., Lin, N. T., Weng, S. F. \& Tseng, Y. H. (1997). The Xanthomonas campestris gumD gene required for synthesis of xanthan gum is involved in normal pigmentation and virulence in causing black rot. Biochem Biophys Res Commun 233, 265-269.

de Mot, R. \& Vanderleyden, J. (1994a). The C-terminal sequence conservation between OmpA-related outer membrane proteins and MotB suggests a common function in both gram-positive and gramnegative bacteria, possibly in the interaction of these domains with peptidoglycan. Mol Microbiol 12, 333-334.

de Mot, R. \& Vanderleyden, J. (1994b). A conserved surface-exposed domain in major outer membrane proteins of pathogenic Pseudomonas and Branhamella species shares sequence homology with the calcium-binding repeats of the eukaryotic extracellular matrix protein thrombospondin. Mol Microbiol 13, 379-380.

Dharmapuri, S. \& Sonti, R. V. (1999). A transposon insertion in the gum $G$ homologue of Xanthomonas oryzae pv. oryzae causes loss of extracellular polysaccharide production and virulence. FEMS Microbiol Lett 179, 53-59.

Dow, J. M., Crossman, L., Findlay, K., He, Y. Q., Feng, J. X. \& Tang, J. L. (2003). Biofilm dispersal in Xanthomonas campestris is controlled by cell-cell signaling and is required for full virulence to plants. Proc Natl Acad Sci U S A 100, 10995-11000.

Dums, F., Dow, J. M. \& Daniels, M. J. (1991). Structural characterization of protein secretion genes of the bacterial phytopathogen Xanthomonas campestris pathovar campestris: relatedness to secretion systems of other gram-negative bacteria. Mol Gen Genet 229, 357-364.

Dye, D. W., Bradbury, J. F., Goto, M., Hayward, A. C., Lelliott, R. A. \& Schroth, M. N. (1980). International standards for naming pathovars of phytopathogenic bacteria and a list of pathovar names and pathotype strains. Rev Plant Pathol 59, 153-168.

Fu, J. F. \& Tseng, Y. H. (1990). Construction of lactose-utilizing Xanthomonas campestris and production of xanthan gum from whey. Appl Environ Microbiol 56, 919-923.

Gotoh, N., Wakebe, H., Yoshihara, E., Nakae, T. \& Nishino, T. (1989). Role of protein F in maintaining structural integrity of the Pseudomonas aeruginosa outer membrane. J Bacteriol 171, 983-990.

Hanahan, D. (1983). Studies on transformation of Escherichia coli with plasmids. J Mol Biol 166, 557-580.

He, Y. W., Xu, M., Lin, K., Ng, Y. J., Wen, C. M., Wang, L. H., Liu, Z. D., Zhang, H. B., Dong, Y. H. \& other authors (2006). Genome scale analysis of diffusible signal factor regulon in Xanthomonas campestris pv. campestris: identification of novel cell-cell communicationdependent genes and functions. Mol Microbiol 59, 610-622.

He, Y. W., Ng, A. Y., Xu, M., Lin, K., Wang, L. H., Dong, Y. H. \& Zhang, L. H. (2007). Xanthomonas campestris cell-cell communication 
involves a putative nucleotide receptor protein $\mathrm{Clp}$ and a hierarchical signalling network. Mol Microbiol 64, 281-292.

Hsiao, Y. M., Fang, M. C., Sun, P. F. \& Tseng, Y. H. (2009). Clp and RpfF up-regulate transcription of pelA1 gene encoding the major pectate lyase in Xanthomonas campestris pv. campestris. J Agric Food Chem 57, 6207-6215.

Hsiao, Y. M., Liu, Y. F., Fang, M. C. \& Tseng, Y. H. (2010). Transcriptional regulation and molecular characterization of the manA gene encoding the biofilm dispersing enzyme mannan endo1,4-beta-mannosidase in Xanthomonas campestris. J Agric Food Chem 58, 1653-1663.

Jackson, D. W., Suzuki, K., Oakford, L., Simecka, J. W., Hart, M. E. \& Romeo, T. (2002). Biofilm formation and dispersal under the influence of the global regulator CsrA of Escherichia coli. J Bacteriol 184, 290-301.

Katzen, F., Ferreiro, D. U., Oddo, C. G., lelmini, M. V., Becker, A., Puhler, A. \& lelpi, L. (1998). Xanthomonas campestris pv. campestris gum mutants: effects on xanthan biosynthesis and plant virulence. J Bacteriol 180, 1607-1617.

Keen, N. T., Tamaki, S., Kobayashi, D. \& Trollinger, D. (1988). Improved broad-host-range plasmids for DNA cloning in gramnegative bacteria. Gene 70, 191-197.

Khan, N. A., Shin, S., Chung, J. W., Kim, K. J., Elliott, S., Wang, Y. \& Kim, K. S. (2003). Outer membrane protein A and cytotoxic necrotizing factor-1 use diverse signaling mechanisms for Escherichia coli $\mathrm{K} 1$ invasion of human brain microvascular endothelial cells. Microb Pathog 35, 35-42.

Koebnik, R., Locher, K. P. \& Van Gelder, P. (2000). Structure and function of bacterial outer membrane proteins: barrels in a nutshell. Mol Microbiol 37, 239-253.

Kostakioti, M., Newman, C. L., Thanassi, D. G. \& Stathopoulos, C. (2005). Mechanisms of protein export across the bacterial outer membrane. J Bacteriol 187, 4306-4314.

Lee, M. C., Weng, S. F. \& Tseng, Y. H. (2003). Flagellin gene $f l i C$ of Xanthomonas campestris is upregulated by transcription factor Clp. Biochem Biophys Res Commun 307, 647-652.

Lin, H. M. \& Tseng, Y. H. (1979). Exopolysaccharide synthesis in Xanthomonas oryzae. Proc Natl Sci Counc Repub China 3, 279284.

Lin, H. M., Tseng, H. C., Wang, C. J., Chyau, C. C., Liao, K. K., Peng, P. L. \& Chou, F. P. (2007). Induction of autophagy and apoptosis by the extract of Solanum nigrum Linn in HepG2 cells. J Agric Food Chem 55, 3620-3628.

Miller, J. H. (1972). Experiments in Molecular Genetics. Cold Spring Harbor, NY: Cold Spring Harbor Laboratory.

Miller, V. L., Farmer, J. J., III, Hill, W. E. \& Falkow, S. (1989). The ail locus is found uniquely in Yersinia enterocolitica serotypes commonly associated with disease. Infect Immun 57, 121-131.

Miller, V. L., Bliska, J. B. \& Falkow, S. (1990). Nucleotide sequence of the Yersinia enterocolitica ail gene and characterization of the Ail protein product. J Bacteriol 172, 1062-1069.

Miller, V. L., Beer, K. B., Loomis, W. P., Olson, J. A. \& Miller, S. I. (1992). An unusual pagC: $\operatorname{Tn} p h o A$ mutation leads to an invasion- and virulence-defective phenotype in salmonellae. Infect Immun 60, 37633770 .

Moore, J., Bailey, S. E., Benmechernene, Z., Tzitzilonis, C., Griffiths, N. J., Virji, M. \& Derrick, J. P. (2005). Recognition of saccharides by the OpcA, OpaD, and OpaB outer membrane proteins from Neisseria meningitidis. J Biol Chem 280, 31489-31497.

Ojanen, T., Helander, I. M., Haahtela, K., Korhonen, T. K. \& Laakso, T. (1993). Outer membrane proteins and lipopolysaccharides in pathovars of Xanthomonas campestris. Appl Environ Microbiol 59, 4143-4151.

Page, R. D. M. (1996). TreeView: an application to display phylogenetic trees on personal computers. Comput Appl Biosci 12, 357-358.

Pal, U., Yang, X., Chen, M., Bockenstedt, L. K., Anderson, J. F., Flavell, R. A., Norgard, M. V. \& Fikrig, E. (2004). OspC facilitates Borrelia burgdorferi invasion of Ixodes scapularis salivary glands. J Clin Invest 113, 220-230.

Prasadarao, N. V., Wass, C. A., Weiser, J. N., Stins, M. F., Huang, S. H. \& Kim, K. S. (1996). Outer membrane protein A of Escherichia coli contributes to invasion of brain microvascular endothelial cells. Infect Immun 64, 146-153.

Rawling, E. G., Brinkman, F. S. \& Hancock, R. E. (1998). Roles of the carboxy-terminal half of Pseudomonas aeruginosa major outer membrane protein OprF in cell shape, growth in low-osmolarity medium, and peptidoglycan association. J Bacteriol 180, 3556-3562.

Ray, S. K., Rajeshwari, R., Sharma, Y. \& Sonti, R. V. (2002). A highmolecular-weight outer membrane protein of Xanthomonas oryzae pv. oryzae exhibits similarity to non-fimbrial adhesins of animal pathogenic bacteria and is required for optimum virulence. $\mathrm{Mol}$ Microbiol 46, 637-647.

Rigano, L. A., Siciliano, F., Enrique, R., Sendin, L., Filippone, P., Torres, P. S., Questa, J., Dow, J. M., Castagnaro, A. P. \& other authors (2007). Biofilm formation, epiphytic fitness, and canker development in Xanthomonas axonopodis pv. citri. Mol Plant Microbe Interact 20, 1222-1230.

Rigden, D. J. \& Galperin, M. Y. (2004). The DxDxDG motif for calcium binding: multiple structural contexts and implications for evolution. J Mol Biol 343, 971-984.

Rojas, C. M., Ham, J. H., Deng, W. L., Doyle, J. J. \& Collmer, A. (2002). HecA, a member of a class of adhesins produced by diverse pathogenic bacteria, contributes to the attachment, aggregation, epidermal cell killing, and virulence phenotypes of Erwinia chrysanthemi EC16 on Nicotiana clevelandii seedlings. Proc Natl Acad Sci U S A 99, 13142-13147.

Sambrook, J. \& Russell, D. W. (2001). Molecular Cloning: a Laboratory Manual, 3rd edn. Cold Spring Harbor, NY: Cold Spring Harbor Laboratory.

Sidhu, V. K., Vorholter, F. J., Niehaus, K. \& Watt, S. A. (2008). Analysis of outer membrane vesicle associated proteins isolated from the plant pathogenic bacterium Xanthomonas campestris pv. campestris. BMC Microbiol 8, 87.

Slater, H., Alvarez-Morales, A., Barber, C. E., Daniels, M. J. \& Dow, J. M. (2000). A two-component system involving an HD-GYP domain protein links cell-cell signalling to pathogenicity gene expression in Xanthomonas campestris. Mol Microbiol 38, 986-1003.

Swings, J. G. \& Civerolo, E. L. (1993). Xanthomonas. London: Chapman \& Hall.

Tadayyon, M., Gittins, J. R., Pratt, J. M. \& Broome-Smith, J. K. (1994). Expression of membrane proteins in Escherichia coli. In Membrane Protein Expression Systems: a User's Guide, pp. 29-83. Edited by G. W. Gould. London: Portland Press.

Tang, J. L., Liu, Y. N., Barber, C. E., Dow, J. M., Wootton, J. C. \& Daniels, M. J. (1991). Genetic and molecular analysis of a cluster of $r p f$ genes involved in positive regulation of synthesis of extracellular enzymes and polysaccharide in Xanthomonas campestris pathovar campestris. Mol Gen Genet 226, 409-417.

Teng, C. H., Xie, Y., Shin, S., Di Cello, F., Paul-Satyaseela, M., Cai, M. \& Kim, K. S. (2006). Effects of ompA deletion on expression of type 1 fimbriae in Escherichia coli K1 strain RS218 and on the association of 
E. coli with human brain microvascular endothelial cells. Infect Immun 74, 5609-5616.

Vieira, J. \& Messing, J. (1991). New pUC-derived cloning vectors with different selectable markers and DNA replication origins. Gene 100, 189-194.

Vorholter, F. J., Schneiker, S., Goesmann, A., Krause, L., Bekel, T., Kaiser, O., Linke, B., Patschkowski, T., Ruckert, C. \& other authors (2008). The genome of Xanthomonas campestris pv. campestris B100 and its use for the reconstruction of metabolic pathways involved in xanthan biosynthesis. J Biotechnol 134, 33-45.

Wang, Y. (2002). The function of OmpA in Escherichia coli. Biochem Biophys Res Commun 292, 396-401.

Wang, T. W. \& Tseng, Y. H. (1992). Electrotransformation of Xanthomonas campestris by RF DNA of filamentous phage phi Lf. Lett Appl Microbiol 14, 65-68.

Wengelnik, K., Marie, C., Russel, M. \& Bonas, U. (1996). Expression and localization of HrpA1, a protein of Xanthomonas campestris pv. vesicatoria essential for pathogenicity and induction of the hypersensitive reaction. J Bacteriol 178, 1061-1069.

William, P. H. (1980). Black rot: a continuing threat to world crucifers. Plant Dis 64, 736-742.

Woodruff, W. A. \& Hancock, R. E. (1989). Pseudomonas aeruginosa outer membrane protein F: structural role and relationship to the Escherichia coli OmpA protein. J Bacteriol 171, 3304-3309.

Yang, B. Y. \& Tseng, Y. H. (1988). Production of exopolysaccharide and levels of protease and pectinase activity in pathogenic and nonpathogenic strains of Xanthomonas campestris pv. campestris. Bot Bull Acad Sin 29, 93-99.

Yang, C. H., Gavilanes-Ruiz, M., Okinaka, Y., Vedel, R., Berthuy, I., Boccara, M., Chen, J. W., Perna, N. T. \& Keen, N. T. (2002). hrp genes of Erwinia chrysanthemi 3937 are important virulence factors. Mol Plant Microbe Interact 15, 472-480.

Edited by: I. K. Toth 